\title{
Nitrogen mineralization after clearcutting and residue management in a second rotation Eucalyptus globulus Labill. stand in Galicia (NW Spain)
}

\author{
Cristina Fernández, José A. VeGA*, Salvador BARÁ, Carmen Beloso, Margarita Alonso, \\ Teresa FONTURBEL
}

Centro de Investigación Forestal-Lourizán, Consellería do Medio rural, Xunta de Galicia, P.O. Box. 127, 36080, Pontevedra, Spain

(Received 25 March 2008; revised version 24 March 2009; accepted 2 June 2009)

\author{
Keywords: \\ harvesting / \\ clearcutting / \\ slash burning / \\ $\mathrm{N}$ mineralization / \\ Eucalyptus globulus / \\ logging residues
}

\begin{abstract}
- The effects of clearcutting and of different slash management procedures on $\mathrm{N}$ mineralization were assessed in a Eucalyptus globulus Labill. stand in Galicia (N W Spain). Treatments were no clearcutting (control), clearcutting combined with scattering, scattering + fertilization, windrowing, and two types of slash burning with two levels of severity: broadcast burning and windrow burning. Changes in mineral $\mathrm{N}$ were monitored in the soil during the 18 months following the treatments. Eleven years later, the treatment effects were again evaluated during a twelve month period to assess long-term effects.

- During the first study period, slash burning led to a marked increase in the contents of $\mathrm{N}-\mathrm{NH}_{4}^{+}$,

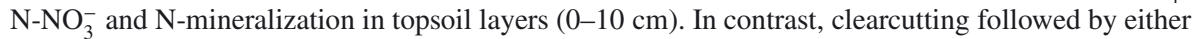
scattering or windrowing of residues had no effect on mineral $\mathrm{N}$ in the top soil or in situ mineralization, relative to the control. Ammonium was the predominant form of mineral N. No residual effects of the treatments were detected eleven years later.

- Fire severity, in relation to slash burn type, had significant negative effects on post-burn $\mathrm{N}$ mineralization and nitrification in the first period studied, but no long-term residual effects were observed. Some practical consequences for sustainable management of such stands are suggested.
\end{abstract}

Mots-clés :

récolte /

coupe à blanc /

écobuage /

minéralisation de l'azote /

Eucalyptus globulus /

résidus d'exploitation
Résumé - Minéralisation de l'azote après coupe à blanc et gestion des résidus dans la deuxième révolution d'un peuplement d'Eucalyptus globulus Labill. en Galice (nord-ouest de l'Espagne).

- Les effets de la coupe à blanc et des différentes procédures de gestion des résidus d'exploitation sur la minéralisation de l'azote ont été évalués dans un peuplement d'Eucalyptus globulus Labill. en Galice (nord-ouest Espagne). Les traitements ont été : pas de coupe à blanc (témoin), coupe à blanc combinée avec dispersion, dispersion + fertilisation, andainage, et deux types d'écobuage à deux niveaux de gravité : incinération par surface et incinération des andains. Les changements en azote minéral ont été suivis dans le sol pendant les 18 mois suivant les traitements. Onze ans plus tard, les effets des traitements ont été de nouveau évalués au cours d'une période de douze mois pour déterminer les effets à long terme.

- Au cours de la première période d'études, l'écobuage a conduit à une nette augmentation de la teneur de $\mathrm{N}-\mathrm{NH}_{4}^{+}, \mathrm{N}^{-\mathrm{NO}_{3}^{-}}$, et à la minéralisation de l'azote dans la couche supérieure du sol $(0-$ $10 \mathrm{~cm}$ ). En revanche, la coupe à blanc suivie d'une dispersion ou d'andainage de résidus n'a eu aucun effet sur l'azote minéral dans la partie supérieure du sol ou sur la minéralisation in situ, par rapport au témoin. L'ammonium a été la forme prédominante de l'azote minéral. Onze ans plus tard, il n'a pas été détecté d'effets résiduels des traitements.

- La gravité des incendies, en relation avec le type d'écobuage, a eu des effets négatifs importants sur la minéralisation de l'azote et la nitrification après le feu dans la première période étudiée, mais des effets résiduels à long terme n'ont pas été observés. Certaines des conséquences pratiques pour la gestion durable de ces peuplements sont proposées.

\footnotetext{
*Corresponding author: jvega.cifal@siam-cma.org
} 


\section{INTRODUCTION}

Elevated concentrations of ammonium and nitrate are frequently observed in soil in clearfelled forest sites (e.g. O'Connell et al., 2004), along with potentially high losses of cations and $\mathrm{N}$ by leaching and/or denitrification (e.g. Gómez-Rey et al., 2007). The accumulation or incorporation of logging residues may modify the soil microclimate and therefore microbial activity (e.g. O'Connell et al., 2004; PérezBatallón et al., 2001). This, along with nutrient release from slash decomposition, may in turn affect $\mathrm{N}$ mineralization processes.

Slash burning may aggravate $\mathrm{N}$ losses through different mechanisms. Losses by volatilization of $\mathrm{N}$ contained in wood, leaf materials and forest floor may occur during slash fires (Raison et al., 1993). Soil heating may also affect microbial populations (Piëtikäinen and Fritze, 1995), the availability of carbon (Almendros et al., 1990), soil nutrients (Ludwig et al., 1998), and alter the soil microclimate (O'Connell et al., 2004). All of these factors may produce notable changes in $\mathrm{N}$ transformation rates.

Careful management of $\mathrm{N}$ is particularly important after clearfelling, because harvest residues may contain a large proportion of $\mathrm{N}$ reserves, which may be lost through inappropriate management. This is especially relevant when burning is used to eliminate logging slash, a common practice in Eucalyptus globulus Labill. plantations in Galicia in the 1990s (Fernández et al., 2004). In laboratory experiments, changes in soil mineral $\mathrm{N}$ and $\mathrm{N}$ mineralization have been found to be related to the levels of heat reached in burned soils (e.g. Klopatek et al., 1990; Serrasolsas and Khanna, 1995), however, there is very little information on the influence of temperatures reached during fire, or other fire behaviour characteristics, measured in field experiments, on soil $\mathrm{N}$ dynamics (e.g. Ellingson et al., 2000; Romanyá et al., 2001).

E. globulus is the most productive forest species in Galicia (NW Spain) and more than 200000 ha are covered by this species in pure stands. The plantations, established in well drained and rather infertile soils, are subjected to intensive silviculture (10-15 y rotation followed by clearcut and timber and bark removal) and logging slash manipulation. Nevertheless, there is very little information about how clearcutting and residue management affect soil nitrogen availability in E. globulus stands in Galicia. Large quantities of $\mathrm{N}$ are removed from the system by tree harvesting (Dambrine et al., 2000; Merino et al., 2005) and logging residues contain significant amounts of nutrients, particularly N (245-450 kg ha-1; Fernández, 2002). Increased $\mathrm{N}$ mineralization may enhance nutrient losses by nitrate leaching, thus exacerbating soil nutrient depletion so that intensive management becomes less sustainable. Research into the $\mathrm{N}$ dynamics of these intensively managed plantations is therefore essential to evaluate the sustainability of current management and to develop alternative forest management policies.

In this study we examined the short and long-term effects of clearcutting and logging slash treatments on soil mineral $\mathrm{N}$ availability in an E. globulus stand in Galicia (NW Spain). We tested the following hypothesis: (1) current clearcutting and logging slash manipulation techniques substantially affect soil $\mathrm{N}$ content and mineralization in the short-term; (2) slash burn has greater effects on $\mathrm{N}$ dynamics than other treatments; (3) fire severity affects $\mathrm{N}$ dynamics; and (4) there is no residual effect of clearcutting and logging slash treatments in the long term.

\section{MATERIALS AND METHODS}

\subsection{Study site}

The study is part of a long-term integrated investigation on the effects of harvesting and associated residue management on soil properties, soil erosion and nutrient budget. It was carried out on the SW slope of the Castrove Mountains ( $42^{\circ} 25^{\prime} 49^{\prime \prime} \mathrm{N} ; 8^{\circ} 44^{\prime} 30^{\prime \prime} \mathrm{W} ; 225 \mathrm{~m}$ a.s.l.) close to the ría Pontevedra, Galicia (NW Spain), a representative location for coastal E. globulus stands in Galicia.

An area in a second-rotation E. globulus stand (15 years old) on a relatively homogeneous slope of $50 \%$ was selected for study in the spring of 1994. Stand density was 1100 trees $\mathrm{ha}^{-1}$, basal area $28 \mathrm{~m}^{2} \mathrm{ha}^{-1}$ and dominant height $25 \mathrm{~m}$. The mean merchantable wood yield for the area is $23 \mathrm{~m}^{3} \mathrm{ha}^{-1}$ year ${ }^{-1}$. The understorey was dominated by Erica cinerea L., Calluna vulgaris (L.) Hull and Ulex europaeus $\mathrm{L}$. The climate is warm-humid oceanic. The average rainfall at the site is $1989 \mathrm{~mm} \mathrm{y}^{-1}$, with a dry period in the summer of one or two months. The mean annual temperature is $14{ }^{\circ} \mathrm{C}$; January is the coldest month (minimum temperature, $2{ }^{\circ} \mathrm{C}$ ) and July the hottest month (maximum temperature, $30^{\circ} \mathrm{C}$ ). The substrate is granite. Soils are Humic Cambisols and Alumi-umbric Regosols with a sandy-loam texture. Stone boulders are frequent. The upper mineral horizon is acidic $(\mathrm{pH}=4.4)$, relatively rich in organic $\mathrm{C}\left(85 \mathrm{~g} \mathrm{~kg}^{-1}\right)$ and has a high total $\mathrm{N}$ content $\left(5.4 \mathrm{~g} \mathrm{~kg}^{-1}\right)$. More information on the characteristics of the soil can be found in Dambrine et al. (2000).

\subsection{Experimental design}

Thirty experimental plots $(30 \times 19 \mathrm{~m}$, each) were established, with the longest dimension along the maximum slope axis. A randomized block design was used. The treatments were: control (no harvested trees); clearcutting + slash scattering; clearcutting + slash scattering + fertilization (100 kg ha ${ }^{-1}$ of which $\left.15 \mathrm{~kg} \mathrm{~N}, 15 \mathrm{~kg} \mathrm{P}, 15 \mathrm{~kg} \mathrm{~K}\right)$; clearcutting + windrowing, clearcutting + slash scattering + burning (broadcast burning), and clearcutting + windrowing + burning (windrow burning). There were five replicates for each treatment.

The methodology followed for evaluation of fuel consumption, fire behaviour and temperatures reached during burning treatments has been described in detail elsewhere (Fernández et al., 2004). Briefly, the main fuel and fire characteristics pertinent to this study are summarized in Table I.

\section{3. $\mathrm{N}$ mineralization, field sampling and analysis}

Net $\mathrm{N}$ mineralization rates in the surface $(0-10 \mathrm{~cm})$ mineral soil were measured by means of in situ soil incubations by the buried polyethylene bag method (Binkley et al., 1992). This widely used method may not reflect the intricate dynamics of $\mathrm{N}$ mineralization in the field (Binkley and Hart, 1989), but nevertheless was preferred to the potential mineralization measured after laboratory incubation, applied in other similar studies (e.g. Choromanska and DeLuca, 2001; 
Table I. Fuel load and selected fire behaviour and temperature regime parameters during E. globulus slash burning. All values are means: the standard error is shown in brackets.

\begin{tabular}{lcc}
\hline & $\begin{array}{c}\text { Broadcast burning } \\
(n=5)\end{array}$ & $\begin{array}{c}\text { Windrow burning } \\
(n=5)\end{array}$ \\
\hline Fuel loads & $63.30(0.44)$ & $114.76(0.74)$ \\
Total pre burn fuel load $\left(\mathrm{t} \mathrm{ha}^{-1}\right)$ & $22.72(0.88)$ & $17.94(0.88)$ \\
Total post burn fuel load $\left(\mathrm{t} \mathrm{ha}^{-1}\right)$ & & \\
Fire behaviour & $4.8(1.8)$ & $9.8(3.7)$ \\
Rate of fire spread $\left(\mathrm{m} \mathrm{min}^{-1}\right)$ & $2(0.5)$ & $3(0.2)$ \\
Flame length $(\mathrm{m})$ & $3114(665)$ & $8808(1803)$ \\
Fire linear intensity $\left(\mathrm{kW} \mathrm{m}^{-1}\right)$ & & \\
Mean maximum temperature $\left({ }^{\circ} \mathrm{C}\right)$ & $487(108)$ & $720(24)$ \\
Litter surface & $204(69)$ & $387(133)$ \\
Mineral soil surface & $47(2)$ & $68(25)$ \\
2 cm below mineral soil surface & & \\
Mean duration of temperature $(s)$ & $258(66)$ & $1544(209)$ \\
$>300{ }^{\circ} \mathrm{C}$ an, litter surface & $60(68)$ & $975(628)$ \\
$>300{ }^{\circ} \mathrm{C}$ an, mineral soil surface & &
\end{tabular}

DeLuca and Zouhar, 2000; Ellingson et al., 2000). We consider that despite its limitations, the in situ incubation method may better reflect the influence of the microenvironmental conditions than laboratory incubations, although the potential $\mathrm{N}$ mineralization rate may be not accurately determined. Furthermore, other more complicated methods of incubation in the field (Raison et al., 1987) have also shown clear limitations in N mineralization studies (Binkley et al., 1992; Jussy et al., 2004; Raison et al., 1987). The basic aim in the present study was not to determine absolute levels of $\mathrm{N}$ mineralization but to compare $\mathrm{N}$ availability between treatments.

Soil incubations began immediately after harvesting and slash disposal or burning (May 1994) and were repeated in June, September and December 1994 and in March, June, September and December 1995 (1st period of study). Soil incubations were also carried out quarterly between September 2005 and June 2006 (2nd period of study) at the same sites. Sampling points $(n=25$ per plot) were selected at random. In windrowed plots, half of the samples were collected under windrows and the rest in the spaces between windrows, so that windrows covered about half of the plot area. A soil core was extracted and carefully divided into two fractions at each sampling point and time. Coarse roots were removed and the sample sieved at $5 \mathrm{~mm}$. One section was brought to the laboratory for extraction and analysis of the initial mineral $\mathrm{N}$ content. The other section was placed in a polyethylene bag with as little disturbance as possible and left in the field until the end of the incubation period (30 d), and the mineral $\mathrm{N}$ content was determined.

Samples were transported to the laboratory in cooled insulated containers, then stored at $4{ }^{\circ} \mathrm{C}$ prior to preparation and initiation of the analysis on the next day. Samples were homogenized manually and a subsample removed for determining the moisture content. The other soil subsample was shaken with $100 \mathrm{~mL}$ of $2 \mathrm{M} \mathrm{KCl}$ for $1 \mathrm{~h}$. The $\mathrm{NH}_{4}^{+}-\mathrm{N}$ was determined colorimetrically following a modified version of the method of Kempers (1974). The $\mathrm{NO}_{3}^{-}-\mathrm{N}$ was determined as nitrite reduction with copperised $\mathrm{Cd}$, by the modified Gries-Ilosvay colorimetric method of Bremner (1965).

Net ammonification and nitrification were estimated by the difference between post and pre incubation concentrations of $\mathrm{NH}_{4}^{+}-\mathrm{N}$ and $\mathrm{NO}_{3}^{-}-\mathrm{N}$, respectively. Nitrogen contents were corrected for soil moisture. Net $\mathrm{N}$ mineralization was obtained by the difference in post and pre-incubation concentrations of $\mathrm{NH}_{4}^{+}-\mathrm{N}+\mathrm{NO}_{3}^{-}-\mathrm{N}$.
Soil bulk density was determined at the end of both study periods in all the experimental plots $(n=30)$. A metal cylinder of $15 \mathrm{~cm}$ diameter was inserted carefully into the upper $5 \mathrm{~cm}$ layer of mineral soil to determine the volume of the soil core; the soil density was then calculated as the ratio between oven-dried soil mass and volume (gravel free) of the soil core. Concentrations of mineral $\mathrm{N}$ are expressed on a dry soil basis. Soil bulk density values were used to calculate the quantities $\left(\mathrm{kg} \mathrm{ha}^{-1}\right)$ of mineral $\mathrm{N}$.

\subsection{Statistical analyses}

Repeated measures analysis of variance was used to test if there were differences ( $95 \%$ probability) in mineral $\mathrm{N}$ content or mineralization content as a result of the different slash treatments applied after clearcutting. Residuals were tested for normality and homogeneity of variance. When significant $(p<0.05)$ differences among treatment levels were detected, the Student-Newman-Keuls multiple range test was used to compare treatment means. Nitrate concentrations and nitrification did not comply with ANOVA assumptions, and the nonparametric multi-comparison Kruskal-Wallis test, followed by a Mann-Whitney U test, was used to determine any significant differences in the responses to the treatments $(p<0.05)$.

A bivariant regression technique was used to examine the possible influence of fire severity related variables and fire intensity on soil ammonium content and nitrogen mineralization in burned plots. Kendall's non parametric correlation test was used for soil nitrate content and nitrification. The differences in the observed values of each $\mathrm{N}$ mineral form for each burned plot and the mean value for the control plots immediately after burning, the annual mean (for the first year following treatment) and the mean for the first and second period of study were considered as dependent variables. The mean values per plot of duration of temperatures $>300{ }^{\circ} \mathrm{C}$ at litter surface, fuel load before burn, total fuel consumption and fire linear intensity were considered as independent variables. The BMDP (1990) and SPSS (2004) statistical packages were used to carry out the analyses.

\section{RESULTS}

\subsection{Inorganic $\mathbf{N}$}

Ammonium was the dominant form of $\mathrm{N}$ in all plots. Slight changes in $\mathrm{NH}_{4}^{+}-\mathrm{N}$ content were observed during the first sampling dates after treatment application (Fig. 1a). Immediately after burning a significantly lower concentration of $\mathrm{NH}_{4}^{+}-\mathrm{N}$ was observed in the soil in the windrowed + burned plots, compared with the control plots. However, from June 1994 onwards only burned soils differed significantly from control soils, with higher values on most dates.

The highest mean quantity of $\mathrm{NH}_{4}^{+}-\mathrm{N}$ was found in windrowed + burned plots (Tab. IIa) followed by broadcast + burned plots for the first study period.

The nitrate concentrations were very variable in the first study period, particularly in burned soils (Fig. 1b) and there were no significant differences between treatments for most of the sampling dates. Mean quantities of nitrate were low (Tab. IIa). Only burned soils contained significantly higher quantities of nitrate than the control and other soils.

No residual effect of harvesting and slash treatments was detected in the concentrations of inorganic- $\mathrm{N}$ forms during the second study period (Fig. 1 and Tab. IIb). 

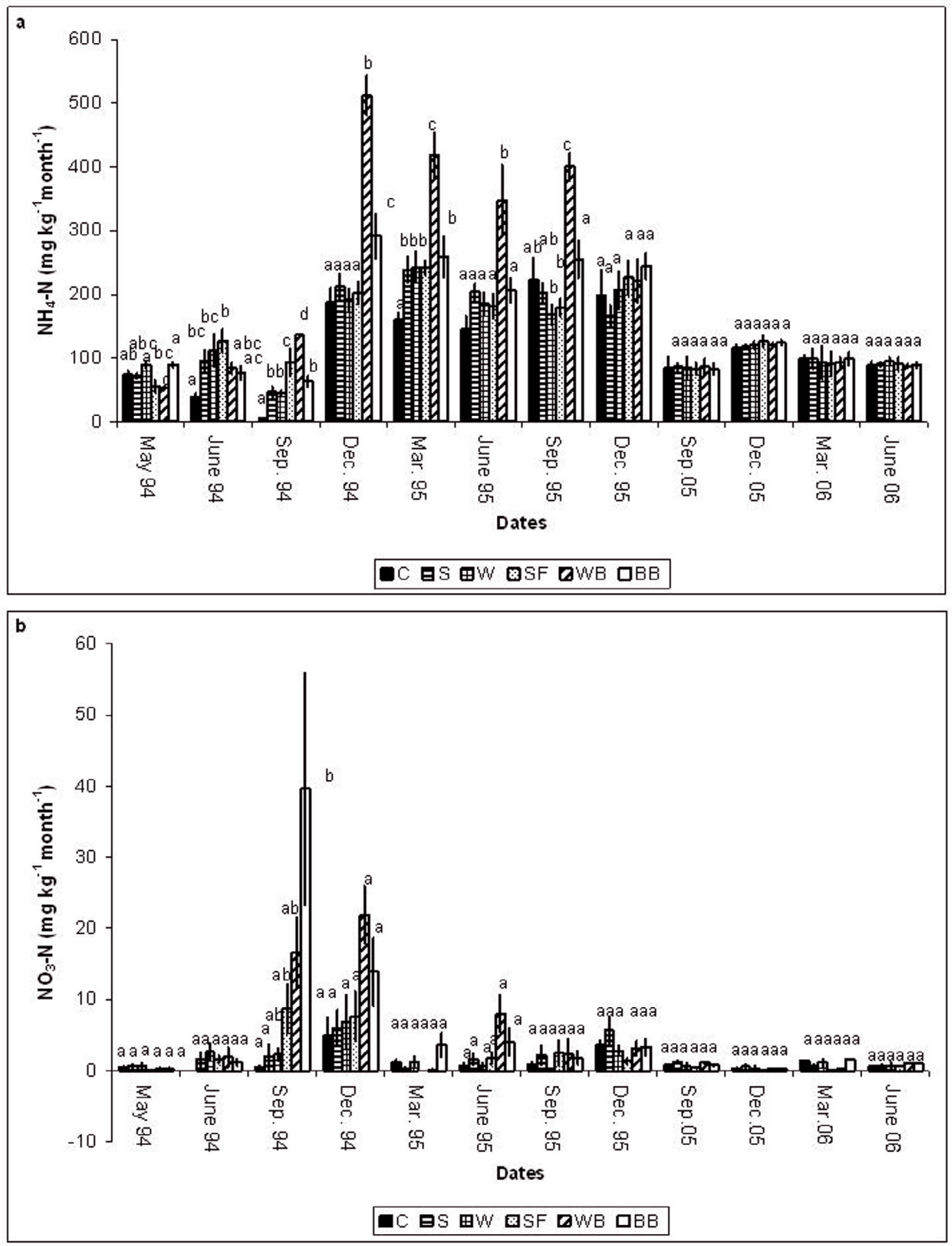

Figure 1. Concentrations of ammonium-N (a) and nitrate-N (b) in surface soil (0-10 cm depth) at different times after harvesting and slash management. Vertical bars, standard error. Note the different scales. C, control (uncut trees); S, clearcutting + slash scattering; SF, clearcutting + slash scattering + fertilization; W, clearcutting + windrowing; BB, clearcutting + broadcast burning; WB, clearcutting + windrow burning. Values indicated by the same letter in the same measurement date did not differ significantly $(p<0.05)$. 
Table II. Mean values of $\mathrm{NO}_{3}^{-}-\mathrm{N}$ and $\mathrm{NH}_{4}^{+}-\mathrm{N}$, net $\mathrm{N}$ mineralization and net nitrification $\left(\mathrm{kg} \mathrm{ha}^{-1} \mathrm{month}^{-1}\right)$ in mineral soil $(0-10 \mathrm{~cm})$ for different E. globulus post-harvesting residue treatments and control during the two study-periods. The standard errors are shown in brackets.

\begin{tabular}{|c|c|c|c|c|}
\hline \multicolumn{5}{|c|}{ (a) First study period (May 1994-December 1995) } \\
\hline Treatment & $\mathrm{NH}_{4}^{+}-\mathrm{N}$ & $\mathrm{NO}_{3}^{-}-\mathrm{N}$ & Net-Mineralization & Net-Nitrification \\
\hline \multirow[t]{2}{*}{ Control (uncut stand) } & $40.60 \mathrm{a}$ & $0.49 \mathrm{a}$ & $32.37 \mathrm{a}$ & $1.19 \mathrm{a}$ \\
\hline & $(13.31)$ & $(0.49)$ & $(8.04)$ & $(1.47)$ \\
\hline \multirow[t]{2}{*}{ Slash scattered } & $49.50 \mathrm{ab}$ & $0.80 \mathrm{a}$ & $40.59 \mathrm{ab}$ & $4.06 \mathrm{a}$ \\
\hline & $(7.21)$ & $(0.42)$ & $(12.28)$ & (10.95) \\
\hline \multirow{4}{*}{$\begin{array}{l}\text { Slash scattered } \\
+ \text { fertilization } \\
\text { Windrowing }\end{array}$} & $54.68 \mathrm{bc}$ & $0.99 \mathrm{a}$ & $54.19 \mathrm{bc}$ & $4.58 \mathrm{a}$ \\
\hline & $(8.29)$ & $(0.91)$ & (11.13) & $(1.85)$ \\
\hline & $49.6 \mathrm{ab}$ & $0.70 \mathrm{a}$ & $31.90 \mathrm{a}$ & $2.87 \mathrm{a}$ \\
\hline & (3.23) & $(0.71)$ & (11.54) & $(2.76)$ \\
\hline \multirow[t]{2}{*}{ Broadcast burning } & $64.04 \mathrm{c}$ & $2.92 \mathrm{~b}$ & $77.88 \mathrm{~d}$ & $15.94 \mathrm{~b}$ \\
\hline & $(8.58)$ & $(2.30)$ & (13.61) & (13.20) \\
\hline \multirow{2}{*}{$\begin{array}{l}\text { Windrowing } \\
+ \text { burning }\end{array}$} & $95.08 \mathrm{~d}$ & $2.38 \mathrm{~b}$ & $66.44 \mathrm{~cd}$ & $8.27 \mathrm{a}$ \\
\hline & $(13.04)$ & $(0.63)$ & $(31.14)$ & $(6.86)$ \\
\hline \multicolumn{5}{|c|}{ (b) Second study period (September 2005-June 2006) } \\
\hline Treatment & $\mathrm{NH}_{4}^{+}-\mathrm{N}$ & $\mathrm{NO}_{3}^{-}-\mathrm{N}$ & Net-Mineralization & Net-Nitrification \\
\hline \multirow[t]{2}{*}{ Control (uncut stand) } & $31.50 \mathrm{a}$ & $0.31 \mathrm{a}$ & $18.71 \mathrm{a}$ & $1.91 \mathrm{a}$ \\
\hline & $(2.22)$ & $(0.05)$ & $(0.39)$ & $(1.70)$ \\
\hline \multirow[t]{2}{*}{ Slash scattered } & $31.41 \mathrm{a}$ & $0.22 \mathrm{a}$ & $20.12 \mathrm{a}$ & $1.52 \mathrm{a}$ \\
\hline & $(1.60)$ & $(0.10)$ & $(0.42)$ & $(1.58)$ \\
\hline \multirow{2}{*}{$\begin{array}{l}\text { Slash scattered } \\
+ \text { fertilization }\end{array}$} & $31.00 \mathrm{a}$ & $0.20 \mathrm{a}$ & $17.40 \mathrm{a}$ & $1.83 \mathrm{a}$ \\
\hline & $(2.31)$ & $(0.16)$ & $(0.68)$ & $(2.00)$ \\
\hline \multirow[t]{2}{*}{ Windrowing } & 30.82 a & $0.12 \mathrm{a}$ & $18.15 \mathrm{a}$ & $1.94 \mathrm{a}$ \\
\hline & $(1.95)$ & $(0.02)$ & $(0.71)$ & $(1.36)$ \\
\hline \multirow[t]{2}{*}{ Broadcast burning } & $31.52 \mathrm{a}$ & $0.53 a$ & $18.12 \mathrm{a}$ & $2.31 \mathrm{a}$ \\
\hline & $(1.20)$ & $(0.05)$ & $(0.29)$ & (1.74) \\
\hline \multirow{2}{*}{$\begin{array}{l}\text { Windrowing } \\
+ \text { burning }\end{array}$} & $31.63 \mathrm{a}$ & $0.31 \mathrm{a}$ & $18.51 \mathrm{a}$ & $2.93 \mathrm{a}$ \\
\hline & $(1.70)$ & $(0.06)$ & $(1.31)$ & $(2.03)$ \\
\hline
\end{tabular}

Values indicated by the same letter in the same column did not differ significantly $(p<0.05)$.

\section{2. $\mathrm{N}$ mineralization}

The mean $\mathrm{N}$ mineralization in burned soils was significantly higher (Tab. IIa) than for control, windrow and slash scattering in the first study period. In fertilized soils $\mathrm{N}$ mineralization was intermediate between that observed in burned and unburned soils. Only broadcast burned soils showed significantly higher $\mathrm{N}$ mineralization than the fertilized soils and the soils subjected to other treatments. Ammonification predominated, and represented on average $90 \%$ of the net mineral $\mathrm{N}$ produced; this ranged from $96 \%$ in control soils to $75 \%$ in broadcast burned soils. There was no apparent immediate response of $\mathrm{N}$ mineralization to harvesting and residue manipulation (Fig. 2a). The only clear response was that net nitrification in broadcast burned soils was higher than in the other soils, in $62.5 \%$ of incubation periods (Fig. 2b).

There were no significant differences among treatments in the second study period, in either $\mathrm{N}$ mineralization or nitrification (Fig. 2 and Tab. IIb).

\subsection{Burning effects on mineral $\mathbf{N}$}

Fire severity, measured as duration of temperatures greater than $300{ }^{\circ} \mathrm{C}$ during slash burning at the litter surface, or fuel load consumption, was positively correlated with mean ammonium content for the first year and the first period after treatments, but negatively affected immediate post-fire concentration of ammonium (Tab. III). Net N-mineralization and nitrification were negatively related to fire severity variables (Tab. III). Duration of high temperatures and fuel consumption were significantly correlated in an exponential relationship $\left(r^{2}=0.73 ; n=9 ; p<0.01\right)$. On the other hand, duration of temperatures $>300{ }^{\circ} \mathrm{C}$ at the litter surface was negatively and exponentially correlated with litter moisture content immediately before burning ( $\left.r^{2}=0.64 ; n=9 ; p<0.02\right)$ and positively and exponentially correlated with pre-burn fuel load $\left(r^{2}=0.64 ; n=9 ; p<0.02\right)$. Fuel load reduction and litter moisture content immediately before burning were also significantly and exponentially related $\left(r^{2}=0.54 ; n=10\right.$; $p<0.05)$.

There were no significant relationships between $\mathrm{N}$ forms and the dependent variables in the second study period.

\section{DISCUSSION}

The results revealed very different responses, in terms of mineral $\mathrm{N}$ content and mineralization, depending on the slash manipulation technique used after harvesting. Unexpectedly, 

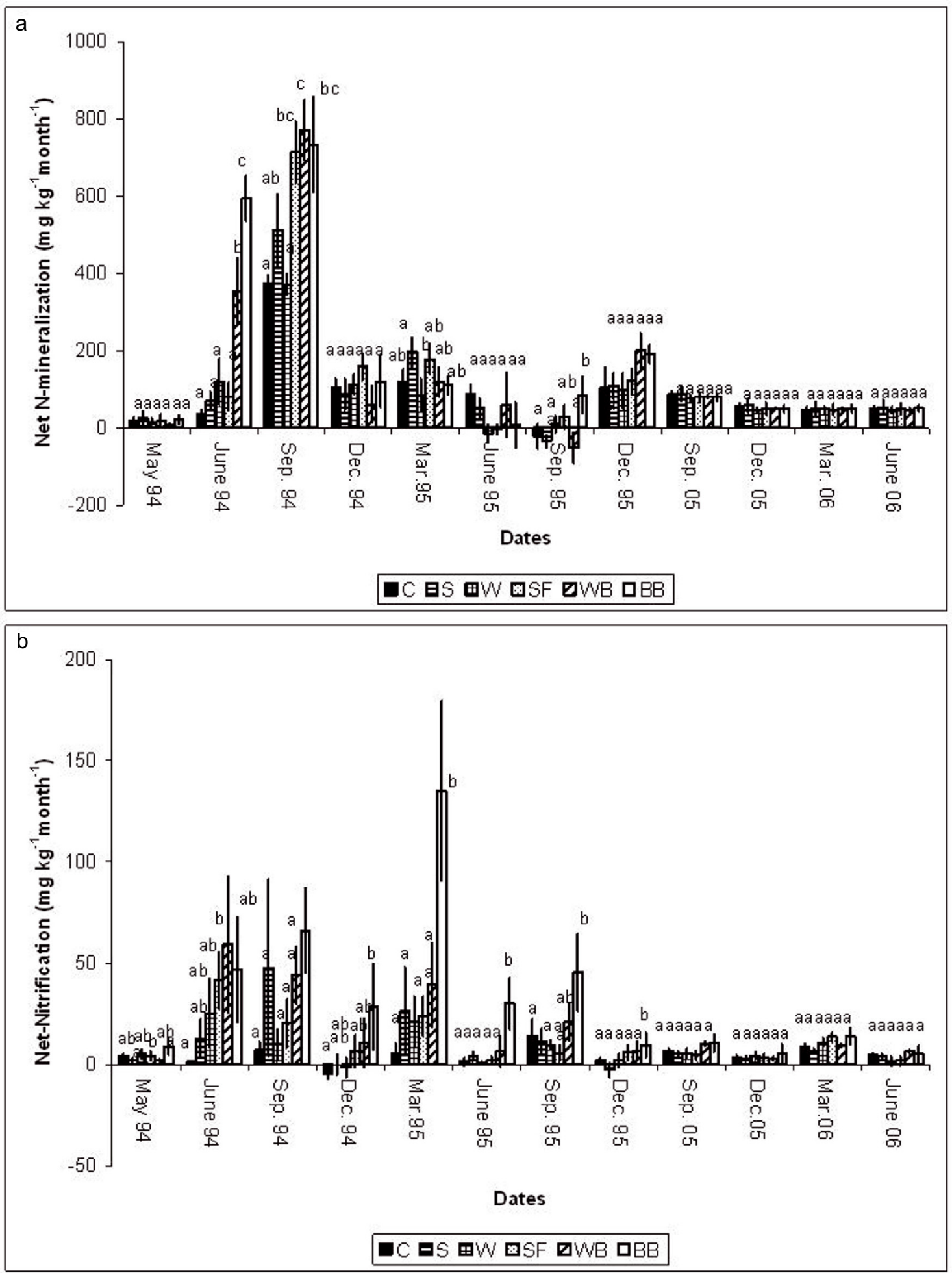

Figure 2. Net mineralization (a) and net nitrification (b) at different times after harvesting and slash management. Vertical bars, standard error. Symbols as in Figure 1. Note the different scales. Values indicated by the same letter in the same measurement date did not differ significantly $(p<0.05)$. 
Table III. Correlations between differences in concentrations of mineral $\mathrm{N}$ forms, net nitrification and net mineralization in burned and control soils, and burning severity parameters. (s.e., standard error).

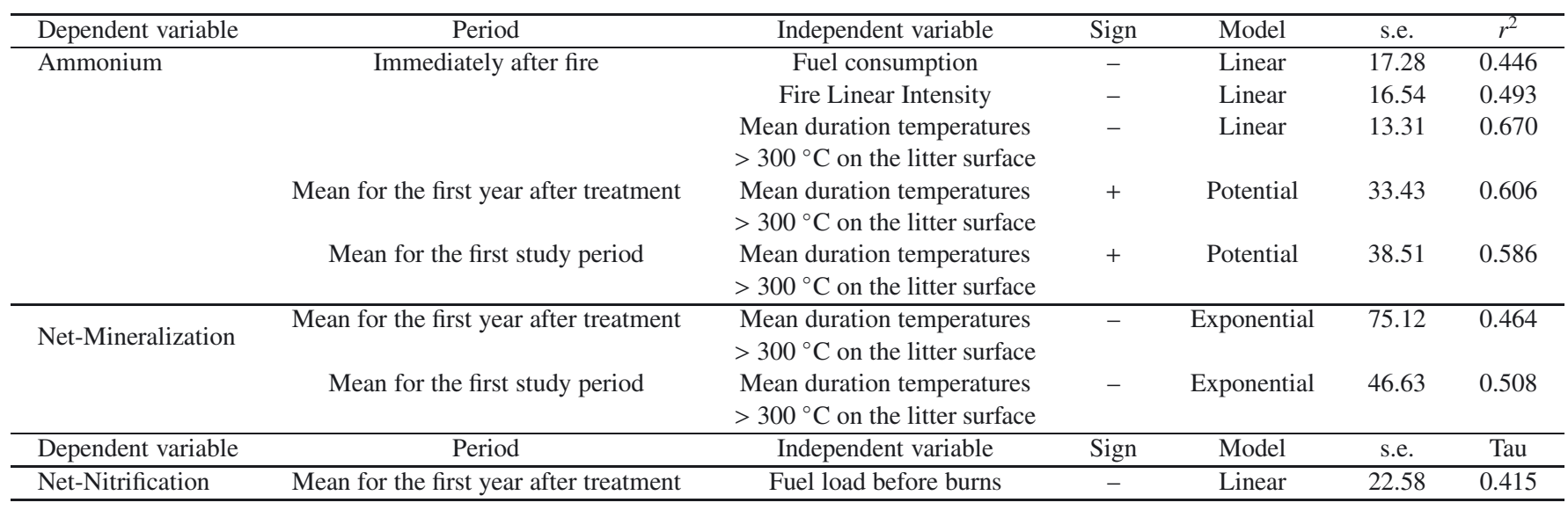

clearcutting followed by scattering or windrowing did not appreciably affect the mean mineral $\mathrm{N}$ content or mineralization, leading to rejection of our first hypothesis. Although a lack of response of mineral $\mathrm{N}$ content after harvesting has also been reported (e.g. Idol et al., 2003), increases in $\mathrm{N}$ mineralization following harvesting are often found (e.g. Giardina and Rhoades, 2001; O'Connell et al., 2004). The present results may be explained by partial $\mathrm{N}$ immobilization, possibly favoured by a high $\mathrm{C}$ content in the soil, mild temperatures and relatively high precipitation in the study site (Gómez-Rey et al., 2007; Pérez-Batallón et al., 2001). The slight increase in mineralization after fertilization, compared with the control, is consistent with the results of other studies (e.g. Magill et al., 1997).

Slash burning caused the most significant changes in $\mathrm{N}$ dynamics, thus confirming our second hypotheses. Adams and Attiwill (1991) and Giardina and Rhoades (2001) also observed increases in $\mathrm{N}$ mineralization after slash burning. Such stimulation of mineralization may be related to an increase in the labile $\mathrm{N}$ forms translocated from organic horizons or slash during fires (Chromanska and De Luca, 2001) or may result from the death of microorganisms (Fritze et al., 1992). The addition of ash may also improve mineralization conditions in acid soils (Raison, 1979). In fact, a positive effect of increased $\mathrm{pH}$ on $\mathrm{N}$ mineralization was detected in the soils under study (Fernández, 2002).

An increase in fire severity was found to favour a decrease in $\mathrm{N}$ mineralization or nitrification, as indicated by the negative relationships observed in Table III, thus, confirming our third hypotheses. This is consistent with the results obtained by Romanyá et al. (2001), who reported a negative correlation between fire severity (maximum temperature and timetemperature integral) and net $\mathrm{N}$-mineralization. A decrease in nitrification with increased fuel consumption after slash burning has also been reported (Ellingson et al., 2000). The above results may be explained by a higher negative impact on microbial populations (Serrasolsas and Khanna, 1995) or on labile $\mathrm{N}$ and $\mathrm{C}$ inputs (Almendros et al., 1990; Giovannini et al., 1990) with increasing severity of fire.
The relationships between the relative increase in ammonium content observed in the first year following burning (and for the first study period) and the duration of temperatures higher than $300{ }^{\circ} \mathrm{C}$ at the litter surface are consistent with the increases in mineral $\mathrm{N}$ with fire severity reported in other studies (e.g. Ellingson et al., 2000; Knoepp et al., 2004).

The decrease in ammonium observed immediately after slash burning had not been observed in previous studies and contrasts with the observations made in such studies (e.g. Choromanska and De Luca, 2001; De Luca and Zouhar, 2000; Ellingson et al., 2000; Giardina and Rhoades, 2001; Knoepp et al., 2004). In the present case, fuel load consumption and the temperature of the mineral soil were high (Tab. I), there was a pronounced thermal gradient in the soil, and soil texture was coarse. All of these factors should have favoured an increase in ammonium immediately after burning (Choromanska and De Luca, 2001; De Luca and Zouhar, 2000), but surprisingly this did not occur. Intense fire may also promote $\mathrm{N}$ losses by direct volatilization (Raison et al., 1993; Serrasolsas and Khanna, 1995), and in this case, high temperatures were reached in the slash during burning, and $\mathrm{N}$ volatilization may have occurred readily. This also appears to be consistent with the negative correlations between the ammonium content and fire severity variables found immediately after burning in the present study. It is also possible that the strong thermal impact on the soil induced changes in the mineral-organic complex (Giovannini et al., 1990; Nishita and Haug, 1972) thereby temporarily altering its capacity to fix $\mathrm{N}-\mathrm{NH}_{4}^{+}$.

The similarity in $\mathrm{N}$ mineralization levels in harvested and control plots 11 years after the treatments suggests a lack of long-term effects of clearcutting and slash treatment on $\mathrm{N}$ availability, as we hypothesized. The reduction in $\mathrm{N}$ mineralization probably did not have any adverse effects on site productivity. It could be argued that the high total carbon and nitrogen levels in these soils, and the environmental conditions with mild temperatures and abundant precipitation, favoured rapid regrowth of eucalyptus and therefore the rapid recovery of the $\mathrm{N}$ mineralization process. Moreover, increases in nitrate concentrations in streamwater in the waterhed were transient, 
and returned rapidly to their baseflow levels after harvesting (Fernández, 2002).

The lack of long-term effects detected in the present study is consistent with previous observations (e.g. Adams and Attiwill, 1991; De Luca and Zouhar, 2000) made after harvest and slash burning.

\section{CONCLUSIONS}

Harvesting and the more conservative slash treatments (scattering and windrowing) surprisingly did not result in significant changes in mineral $\mathrm{N}$. This is consistent with the conservative behaviour observed in these eucalypt stands, in which nutrient outputs in total runoff are usually lower than rainfall inputs (Dambrine et al., 2000), as well as with the absence of signs of $\mathrm{N}$ deficiency and sustained growth of these stands. However, the results must be compared with $\mathrm{N}$ output measured via total runoff after harvesting .

The lack of response of mineral $\mathrm{N}$ immediately after burning was not anticipated. The reason for the delay in response is not clear, although the results strongly suggest that it was related to the greater severity of the fire. However, in the short term, increases in fire severity resulted in decreases in $\mathrm{N}$ mineralization and nitrification.

From the perspective of operational management of forest residues, the litter moisture content and fuel load before burning had a significant effect on soil heating and fuel consumption. If E. globulus slash burning is prescribed to reduce fire hazard, it must be conducted with high litter moisture content, and high slash accumulation should be avoided not only because of undesired effects on $\mathrm{N}$ dynamics but also to reduce possible degradation of physical soil properties and soil erosion (Fernández et al., 2004). However, although windrow burning led to greater losses of $\mathrm{N}$ from the system than broadcast burning, paradoxically, the latter gave rise to twice the amount of mineralized nitrate than the former, with the subsequent higher risk of cation leaching in these desaturated soils. Apparently, the latter would make these intensively managed stands less sustainable. Although this demonstrates the complexity of the $\mathrm{N}$ mineralization response after fire and that additional research is required to clarify these points, treatments such as burning, which simultaneously enhances total $\mathrm{N}$ losses and risk of cation leaching, obviously should be avoided in soils such as those under study.

Acknowledgements: This study was funded by the National Institute of Agricultural Research of Spain (INIA) and R+D General Directorate of the Xunta de Galicia through projects SC-93-096 and PGIDIT05RFO50202PR, respectively. This work was also cofinanced by European Social Funds (Dr. C. Fernández). We are grateful to Antonio Arellano for valuable field assistance in the selection of the experimental sites, plot installation, experimental burnings and periodic field measurements. We are also grateful to all those who helped with field work and laboratory analyses, particularly José R. González, Elena Pérez, Angela López and José $\mathrm{M}^{a}$ Mendaña. We also like to thank the Forestry Service of the Galician Department of Environment (Consellería de Medio Ambiente) and in particular José Gea and the owners of the Comunidad de Montes de Meis. We sincerely acknowledge the critical reviews of the editor and the anonymous referees who helped improve an early version of the manuscript.

\section{REFERENCES}

Adams M.A. and Attiwill P.M., 1991. Nutrient balance in forests of northern Tasmania.2. Alteration of nutrient availability and soil-water chemistry as a result of logging, slash burning and fertilizer application. For. Ecol. Manage. 7: 241-248.

Almendros G., González-Vila F.J., and Martín F., 1990. Fire induced transformations on soil organic matter from an oak forest: an experimental approach to the effects of fire in humic substances. Soil Sci. 149: $158-168$.

Binkley D. and Hart S.C., 1989. The components of nitrogen availability assessments in forest soils. Adv. Soil Sci. 10: 57-112.

Binkley D., Bell R., and Sollins P.,1992. Comparison of methods for estimating soil nitrogen transformations in adjacent conifer and alderconifer forests. Can. J. For. Res. 22: 858-863.

BMDP.1990. BMDP Statistical Software Inc. Los Angeles. USA.

Bremner J.M., 1965. Inorganic forms of nitrogen. In: Black et al. (Eds.), Methods of soil analysis. Part 2., Am. Soc. Agrom. Madison. Wis. Agronomy 9: 1179-1237.

Choromanska U. and De Luca T.H., 2001. Prescribed fire alters the impact of wildfire on soil biochemical properties in a ponderosa pine forest. Soil Sci. Soc. Am. J. 65: 232-238.

Dambrine E., Vega J.A., Taboada T., Rodríguez L., Fernández C., Macías F., and Gras J.M., 2000. Bilans d'eléments minéraux dans de petits bassins versants forestiers de Galice (NW Espagne). Ann. For. Sci. 57: $23-38$

De Luca T.H. and Zouhar K.L., 2000. Effects of selection harvest and prescribed fire on the soil nitrogen status of ponderosa pine forests. For. Ecol. Manage. 138: 263-271.

Ellingson L.J., Kauffman J.B., Cummings D.L., Standford R.L. Jr, and Jaramillo V.J., 2000. Soil N dynamics associated with deforestation, biomass burning and pasture conversion in a Mexican tropical dry forest. For. Ecol. Manage. 137: 41-51.

Fernández C., 2002. Influencia de actuaciones selvícolas y perturbaciones en el balance hídrico y dinámica de nutrientes en cuencas experimentales. Su conexión con la sostenibilidad de la selvicultura intensiva en especies forestales de crecimiento rápido en Galicia. Phis. Diss. Vigo University, $508 \mathrm{p}$.

Fernández C., Vega J.A., Gras J.M., Fonturbel T., Cuiñas P., Dambrine E., and Alonso, M., 2004. Soil erosion after Eucalyptus globulus clearcutting: differences between logging slash disposal treatments. For. Ecol. Manage. 195 (1-2): 85-95.

Fritze H., Pennanen T., and Pietikäinen J., 1992. Recovery of soil microbial biomass and activity from prescribed burning. Can. J. For. Res. 23: $1286-1290$.

Giardina C.P. and Rhoades C.C., 2001. Clear cutting and burning affect nitrogen supply, phosphorus fractions and seedling growth in soils from a Wyoming lodgepole pine forest. For. Ecol. Manage. 140: $19-28$.

Giovannini G., Lucchesi S., and Giachetti M., 1990. Effects of heating on some chemical parameters related to soil fertility and plant growth. Soil Sci. 149: 344-350.

Gómez-Rey M.X., Vasconcelos E., and Madeira M., 2007. Lysimetric study of eucalypt residue management effects on $\mathrm{N}$ leaching and mineralization. Ann. For. Sci. 64: 699-706.

Idol T.W., Pope P.E., and Ponder Jr. F., 2003. N mineralization, nitrification, and $\mathrm{N}$ uptake across a 100-year chronosequence of upland hardwood forests. For. Ecol. Manage. 176: 509-518.

Jussy J.-H., Ranger J., Bienaimé S., and Dambrine E., 2004. Effects of a clear-cut on the in situ nitrogen mineralisation and the nitrogen cycle in a 67-year-old Douglas-fir (Pseudotsuga menziesii (Mirb.) Franco) plantation. Ann. For. Sci. 61: 297-408. 
Kempers A.J. 1974. Determination of sub-microquantities of ammonium and nitrates in soils with phenol, sodium, nitroprusside and hypochlorite. Geoderma. 12: 201-206.

Klopatek J.M., Klopatek C.C., and De Bano L.F., 1990. Potential variation of nitrogen transformations in pinyon-juniper ecosystems resulting from burning. Biol. For. Soils. 10: 35-44.

Knoepp J.D., Vose J.M., and Swank W.T., 2004. Long-term soil responses to site preparation burning in the Southern Appalachians. For. Sci. 50: $540-550$

Ludwig B., Khanna P.K., Raison R.J., and Jacobsen K.L., 1998. Modelling cation composition of soil extracts under ashbeds following an intense slashfire in a eucalypt forest. For. Ecol. Manage. 103: 9-20.

Magill A.H., Aber J.D., Hendriks J.J., Bowden R.D., Stendler P.A., and Melillo, J.M., 1997. Biogeochemical response of forest ecosystems to simulated chronic nitrogen depositions. Ecol. Appl. 7: 402-415.

Merino A., Balboa M.A., Rodríguez Soalleiro, R., and Alvarez González J.G., 2005. Nutrient exports under different harvesting regimes in fast-growing forest plantations in southern Europe. For. Ecol. Manage. 207: 325-339.

Nishita H. and Haug R.M., 1972. Soil physical and chemical characteristics of heated soils. Soil Sci. 113: 422-430.

O'Connell A.M., Grove T.S., Medham D.S., and Rance S.J., 2004. Impact of harvest residue management on soil nitrogen dynamics in Eucalyptus globulus plantations in south western Australia. Soil Biol. Biochem. 36: 39-48.
Pérez-Batallón P., Ouro G., Macías F., and Merino A., 2001. Initial mineralization of organic matter in a forest plantation soil following different logging residue management techniques. Ann. For. Sci. 58: $807-818$.

Pietikäinen J. and Fritze H., 1995. Clear-cutting and prescribed burning in coniferous forests: comparison of effects on soil fungal and total microbial biomass, respiration and nitrification. Soil Biol. Biochem. 27: $229-240$.

Raison R.J., 1979. Modification of the soil environment by vegetation fires, with particular reference to nitrogen transformations: A review. Plant Soil. 51: 73-108.

Raison R.J., O’Connell A.M., and Khanna P.K., 1987. Methodology for studying fluxes of soil mineral-N in situ. Soil Biol. Biochem. 19: 521-530.

Raison R.J., O'Connell A.M., Khanna P.K., and Keit H., 1993. Effect of repeated fires on nitrogen and phosphorus budgets and cycling processes in forest ecosystems. In: Trabaud L. and Prodon R. (Eds.), Fire in Mediterranean Ecosystems, CEC, Brussels-Luxembourg, pp. $347-363$.

Romanyá J., Casals P., and Vallejo V.R., 2001. Short-term effects of fire on soil nitrogen availability in Mediterranean grasslands and shrublands growing in old fields. For. Ecol. Manage. 147: 39-53.

Serrasolsas I. and Khanna P.K., 1995. Changes in heated and autoclaved forest soils of S.E. Australia. I. Carbon and nitrogen. Biogeochemistry. 29: 3-24.

SPSS, 2004. User's Manual, Ireland. 